Received: July 15, 2016

\title{
The Abstraction Process of Limit Knowledge
}

\author{
Dilek Sezgin Memnun ${ }^{1}$ \\ Uludag University
}

\author{
Bünyamin Aydın² \\ Necmettin Erbakan \\ University \\ Güneş Erdoğan ${ }^{4}$ \\ Necmettin Erbakan University
}

\author{
Ömer Özbilen ${ }^{3}$ \\ Mersin University
}

\begin{abstract}
The $\mathrm{RBC}+\mathrm{C}$ abstraction model is an effective model in mathematics education because it gives the opportunity to analyze research data through cognitive actions. For this reason, we aim to examine the abstraction process of the limit knowledge of two volunteer participant students using the $\mathrm{RBC}+\mathrm{C}$ abstraction model. With this aim, the students' abstraction processes were examined over recognition, building-with, construction, and consolidation. In the process, three problems that enable students to use their pre-knowledge were designed by the researchers to reveal the students' mathematical thinking levels, abstraction processes, and finally to improve a new structure. These problems were used in the application, and students' dialogues were videorecorded. The semi-constructed interview and observation data-collection methods were used in this process, and one of the researchers participated in the study as a participant observer. The data was analyzed and interpreted by transcribing the video recordings into written text and grouping them into the cognitive actions of the $\mathrm{RBC}+\mathrm{C}$ model. In conclusion, these students were indicated to have managed recognizing and buildingwith their pre-knowledge on sequence, function, and infinity, and thus constructing knowledge on limits.
\end{abstract}

\section{Keywords}

Abstraction • Building-with $\bullet$ Construction $\bullet$ Limit $\bullet$ RBC + C Abstraction model

\footnotetext{
1 Correspondence to: Dilek Sezgin Memnun (PhD), Department of Elementary Education, Faculty of Education, Uludag University, Nilüfer, Bursa 16059 Turkey. Email: dsmemnun@uludag.edu.tr

2 Department of Mathematics Education, Ahmet Keleşoğlu Faculty of Education, Necmettin Erbakan University, Meram, Konya 42090 Turkey. Email: bunyaminaydin63@hotmail.com

3 Department of Tarsus Vocational High School, Mersin University, Tarsus, Mersin 33400 Turkey. Email: ozbilen@mersin.edu.tr

4 Institute of Educational Sciences, Ahmet Keleşoğlu Faculty of Education, Necmettin Erbakan University, Meram, Konya 42090 Turkey. Email: gunes.erdogan0914@gmail.com
}

Citation: Sezgin Memnun, D., Aydın, B., Özbilen, Ö., \& Erdoğan, G. (2017). The abstraction process of limit knowledge. Educational Sciences: Theory \& Practice, 17, 345-371. http://dx.doi.org/10.12738/estp.2017.2.0404 
Limits are a basic and important concept in mathematics. They can be assumed as one of the most fundamental concepts and influential instruments of general mathematics because they lead especially to the understanding of derivations and integrals (Çıldır, 2012; Çoker, Özer, \& Taş, 1989). In other words, limit knowledge is a pre-concept related to many important mathematical concepts such as derivatives, integrals, continuities, and convergences. Therefore, it also constitutes an important role in high school and college mathematics curricula.

\section{Knowledge and Historical Development of Limits}

Limits were used in theorems related to shapes with curvilinear sides in early times. Euclid and Archimedes used this concept for the first time. For example, Archimedes used them to calculate the area of a circle. In his justification, the area of the circle is equal to the area of a right triangle whose base equals the circle's circumference and whose height equals the circle's radius. In this process, the circle is assumed to be a straight line equal to the circumference of it. He calculated the inferior and superior limits to find the straight line in this justification (Cajori, 2014, p. 25). However, the use of limits with the same current meaning was based on work from the 17th century. For example, Fermat examined the interrelation between the limit of a curve at a point on the graph and the tangent of that point of the curve (Baki, 2008, p. 147). Afterwards, the researchers Newton and Leibniz used limits to calculate integrals. In other words, differential equations emerged from knowledge on limits (Baki, 2014, p. 145). Newton can be said to have used this concept in general, not for any specific purpose. He used it to extrapolate a few different principles used for a variety of purposes (Cajori, 2014, p. 234). Similarly, the area under the curve of $y=x^{2}$ restricted for $0<x<1$ was shown to be $1 / 3$ by Cavalieri using limit knowledge (Baki, 2008, p. 146). Meanwhile, the definition of the limit was not given until 1817 by Bolzano. Additionally, Weierstrass and Cauchy indicated limits were applied in calculus nineteenth century (Arslan \& Çelik, 2015, p. 483; Baki, 2008, p. 149). Formal and informal definitions can be given for limit knowledge. In calculus, the epsilon-delta definition of limit is a formalization of the notion of limit (Balc1, 2014).

\section{Difficulties in Learning and Teaching Limits}

These days, difficulties and misconceptions about limit knowledge are encountered by students as learning the subject of limits brings along serious difficulties for students in the advanced subjects of high-school curriculum. Because limits contain different procedures that include infinity in particular, they are also not a simple subject (Baştürk \& Dönmez, 2011; Tangül, Barak, \& Özdaş, 2015). Most students cannot place the knowledge of limits in their minds and for this reason have difficulty making sense of it; as a result, students have trouble learning limit knowledge (Çıldır, 
2012). Specifically, they have difficulty performing operations related to limits. This situation has been reflected in different studies. Within this context, Durmuş (2004); Gürbüz, Toprak, Yapıc1, and Doğan (2011); and Tatar, Okur, and Tuna (2008) aimed to determine difficult subjects in mathematics courses and to reveal the roots underlying these difficulties. Thus all of these studies found the subject of limits taking place at the top of subjects which students perceive as difficult. The desire to uncover the difficulties with limits is the main reason why the number of studies made on this concept has increased (Baştürk \& Dönmez, 2011).

Some limit-knowledge studies (Barak, 2007; Baştürk \& Dönmez 2011; Denbel, 2014; Juter, 2006; Szydlik, 2000; Tangül et al., 2015) revealed students' difficulties and misconceptions. In the studies by Barak (2007) and Baştürk and Dönmez (2011), students were determined to have different misconceptions about limit knowledge. In this context, Barak (2007) explained these misconceptions as errors and misconceptions about the epsilon-delta definition, the definition of limits, a function's limit at a point, limits approaching from the right and the left, the relation between the concepts of limits and continuity, a function that is defined at a single point, graphing functions, understanding the concept of infinity, and using the limit in equations. Additionally, Baştürk and Dönmez summarized pre-service teachers' misconceptions that limit should be defined and extend from a function at a single point while being the limit of a function at the same point. Similarly, limits do not exist when a diagram is not continuous or when there are omissions/fractions in it. Denbel (2014) indicated that university students see a limit as unreachable, an approximation, a boundary, or a dynamic process. Also, Denbel declared that students have many misconceptions, such as limits representing the value of a function at a point, a limit can be found though a method of substitution, or that one divided by zero equals zero. Juter (2006) reported that students have many different cognitive difficulties related to limit knowledge, such as infinite series and how functions never reach their limits. Szydlik (2000) declared that limit beliefs and understanding are highly related to one another. Similarly, Tangül et al. (2015) stated that most university students have trouble expressing limits and using its formal definition.

\section{Methods for Teaching and Learning Limits}

Some studies (Akbulut \& Işık, 2005; Akkoyunlu, Güler, Uğurel, \& Alan, 2003; Biber \& Argün, 2015; Bukova-Güzel, 2007; Çıldır, 2012; Dönmez \& Baştürk, 2010; Kula \& Bukova-Güzel, 2015a, 2015b; Przenioslo, 2004; Roh, 2007; Tangül et al., 2015) have investigated how students learn limits and have given room to some teaching studies with the aim of eliminating their difficulties and misconceptions in relation to limit knowledge. As a result of Akbulut and Işık's (2005) study, a new interactive teaching strategy was declared to be influential on teaching limit knowledge. Akkoyunlu et al. 
(2003) explained that animations, activities, scenarios, and worksheets can be used as course content to clarify high-school students' limit knowledge so as to overcome their difficulties. In this study, misconceptions are also stated as preventable by focusing on how a function's appearance behaves when the function's independent variable is infinitely small. Biber and Argün (2015) indicated that university students have structured limit knowledge on double variable functions mostly by making expansive generalizations. They also explained that candidates are not successful enough, which requires reconstructing their generalization processes. Çıldır (2012) declared that using computer-based demonstrations could be beneficial for teaching limits and overcoming related misconceptions. Dönmez and Baştürk (2010) declared that current teachertraining programs are insufficient and improper at teaching pre-service teachers how to integrate different strategies. Kula and Bukova-Güzel (2015a) declared that preservice teachers' thoughts about current mathematics programs related to limits are composed under the headings of relating real life to limit knowledge, relating them in different areas, providing mathematical thinking and reasoning, improving the ability to communicate, using mathematical language, relating mathematics with art, and using technology effectively. Kula and Bukova-Güzel (2015b) investigated which special methods pre-service teachers use in mathematics for limits. They indicated that preservice teachers' preferred methods for teaching limits are limit-specific representations and activities. Their participants used mostly verbal and algebraic representations. Przenioslo (2004) declared that students generally interpret the formal definition of limit as an equation. Roh (2007) explained that a female student who was engaged in the $\varepsilon$-strip activity understood as a whole the concept and formal definition of the limit of a sequence. Tangül et al. (2015) explained that most university students do not interrelate concept images and formal definitions but use concept images to solve limit problems. Moreover, Bukova-Güzel (2007) reported that mathematics education departments promote learning limit knowledge through a constructivist learning environment.

\section{Abstraction, the Abstraction Process, and the RBC+C Abstraction Model}

Along with attaching more importance to conceptual learning in these renewed programs, abstraction has also gained importance. Conceptual learning entails the abstraction of a concept. For this reason, such matters as construction and abstraction, which require examining individuals' abstraction processes, have become important research subjects in the learning domain of mathematics. Moreover, mathematics is a science of abstraction, and the great majority of mathematical concepts are obtained through abstraction (Altun, 2014, p. 5). This makes it especially important to overcome the abstraction process of concepts in math education. Because of this, determining how to develop abstractions and generalizations that students carry out with the help of their foreknowledge becomes important (Bukova-Güzel, 2006, 2007). As a result, this study examines how $12^{\text {th }}$-grade students learn and abstract limit knowledge. 
Abstraction is a structural process, the construction of mental structures from mathematical structures, as well as mathematical structures from mental structures. It is the process of detaching a characteristic or characteristics that objects have in common with other objects and giving names to these characteristics. The abstraction process is not a directly observable state. It takes place in the form of isolating a concept from its specific characteristics and directing the process from a set of contexts toward a concept (Dreyfus, 2007; Mitchelmore, 2002; Sierpinska 1994; Tall, 1988; Y1lmaz, 2011). Also, mathematical abstraction provides opportunities for constructing mathematical concepts, as well as achieving the transition between concepts and, most importantly, comprehension not through memorization but through conceptualization (Can, 2011). For this reason, the theme of abstraction occupies an important place throughout one's mathematical education.

Different models have been developed and used for abstraction. One of these is the $\mathrm{RBC}+\mathrm{C}$ (recognizing, building-with, construction, and consolidation) abstraction model. According to this model, one needs to rearrange old structures in order to reach a new structure, establish connections and relationships between them, and integrate them into a single thought process. This model allows analyzing students' knowledge construction through the cognitive actions of recognizing, building-with, construction, and consolidation. In this abstraction process, abstraction is formed by passing three steps. The first is the need for a new structure. The second is the formation of a new abstract entity that processes the actions of recognizing and building-with as existing structures are intermingled. The third one is consolidating abstraction in such a way as to facilitate a person's recognition. Additionally, abstraction occurs in a problem-solving process in which the student performs the action of formation using a new method (Hershkowitz, Schwarz, \& Dreyfus, 2001). While forming a piece of knowledge, an individual makes associations with previous subject matter in the recognizing stage, uses it for problem-solving in the building-with stage, sets up a new knowledge structure in the construction stage, and reinforces the formed knowledge in the consolidation stage. Abstraction emerges by requiring further construction and also covers strengthening (Tsamir \& Dreyfus, 2002). The act of construction forms as a result of the materialization of recognizing and building-with, which are nested in one another (Dreyfus, 2007; Dreyfus, Hershkowitz, \& Schwarz, 2001b). Thus, the $\mathrm{RBC}+\mathrm{C}$ model is important because it enables one to examine the abstraction process over cognitive ones (Dreyfus, 2007; Dreyfus, Hershkowitz, \& Schwarz, 2001a, 2001b; Herskhowitz et al., 2001). Each of these actions is observable; the abstraction process can be recognized deeply by observing them (Altun \& Y1lmaz, 2008) and is appropriate for this research.

This abstraction model has been examined using various mathematical concepts in different studies: the greatest integer function (Altun \& Y1lmaz, 2008), algebra 
and properties of arithmetic operations (Dreyfus et al., 2001a, 2001b), ratios (Hassan \& Mitchelmore, 2006), and probabilities (Dreyfus, Hadas, Hershkowitz, \& Schwarz, 2006; Hershkowitz, 2004; Schwarz, Dreyfus, Hadas, \& Hershkowitz, 2004). In addition, functions (Hershkowitz et al. 2001), absolute value (Özmantar, 2004, 2005), linear equations (Sezgin-Memnun \& Altun, 2012), infinity (Tsamir \& Dreyfus, 2002), and triangles along with its variations (Yeşildere \& Türnüklü, 2008a, 2008b) have been explored in particular.

\section{Limit Knowledge in Turkish Mathematics Course Programs}

Limit knowledge had been taught intuitively without a formal definition given to students prior to the changes in mathematics course programs in Turkey in recent years (Ministry of Education [MEB], 2006). After the changes in the programs, constructivist learning first began its use in programs for all mathematical subjects, and also the subject of limits has occurred in different grades in mathematics programs in recent years. Finally, the subject of limits has nine different acquisitions and takes twelve hours to teach and learn (MEB, 2013) per the latest version of the reorganized programs. Also, the acquisition of limits is explained in the course programs. Some of these are:

1. Explain an independent variable approaching a given number with examples.

2. Explain limits at a point of a function, the limit approaching from the right or left, with examples. One should explain the relation between a limit approaching from the right and one from the left.

3. Explain the properties of limits; make exercises for them.

4. Make exercises related to the limit of functions.

Which additional strategies can be appropriate for teaching limit knowledge has not been detailed (Kula \& Bukova-Güzel, 2015b; MEB, 2013). Because of that, different strategies have been attempted in different studies (Akbulut \& Iş1k, 2005; Akkoyunlu et al., 2003; Bukova-Güzel, 2007; Çıldır, 2012).

\section{Objectives}

Different studies have emphasized the importance and need to research the learning process of limits, which have an important place in mathematics. Also, students have trouble constructing limit knowledge. Because of this, some studies (Barak, 2007; Baştürk \& Dönmez 2011; Denbel, 2014; Juter, 2006; Szydlik, 2000; Tangül et al., 2015) have investigated students' misconceptions about limits, and others have tried to solve them with new teaching and learning strategies. For example, Akbulut and Iş1k 
(2005) tried to teach the concept using an interactive teaching strategy, Çıldır (2012) used computer-generated visualization, Bukova-Güzel (2007) applied constructivist learning, and Akkoyunlu et al. (2003) used animations, activities, and scenarios to eliminate students' difficulties and misconceptions. Similar to Bukova-Güzel's (2007) research, yet different from all previous studies, the constructivist learning approach has been used in this research, as it is appropriate for abstracting limit knowledge. Abstracting limit knowledge has been explored through constructivist learning using the $\mathrm{RBC}+\mathrm{C}$ abstraction model in this research. Limit knowledge was chosen for this research due to the subject's complexity and abstract concepts (Çoker et al., 1989). Limit knowledge is also appropriate for carrying out this study using the $\mathrm{RBC}+\mathrm{C}$ abstraction model because one component of the abstraction process is to have a mathematical entity (Özmantar \& Monaghan, 2007). Additionally, very few studies related to limit knowledge have focused on high-school grades. However, the abstraction process in this research is carried out with high-school students within an appropriate context because giving knowledge directly to the students who have trouble comprehending something structurally abstract does not lead them to build but to memorize this knowledge. The limit problems chosen by the researchers for this study also contain different contexts, which is valuable and meaningful to students. Accordingly, the research problem in this study has been quantified as "How do $12^{\text {th }}$ grade students abstract limit knowledge?"

This study differs from other studies on the subject of limits in that it allows $12^{\text {th }}$ grade students' abstraction process for limits to be examined through constructivist learning, as well as the learning processes in detail using the $\mathrm{RBC}+\mathrm{C}$ abstraction model. Moreover, this study is considered to contribute to the field by allowing for an understanding of students' insufficient knowledge and misconceptions regarding limits and a determination of the distinct ways students use in their learning process.

\section{Method}

This section includes information about the research model, the participating students, and their abstraction process when learning using the $\mathrm{RBC}+\mathrm{C}$ abstraction model. In this study, a significant amount of data has been obtained from a limited number of students, and the abstraction process has been evaluated very clearly. Therefore, this study is defined as a case study.

Case studies offer a convenient model for examining a highly detailed specific phenomenon, such as a person, a process, an operation, or an institution. In qualitative case studies, the researcher(s) explores a process, questions may address a case description, and the themes emerge from this (Creswell, 2009, p. 130). Additionally, choosing a single case can provide detailed and significant knowledge (Vural 
\& Cenkseven, 2005). The case in this research is the detailed examination of the abstraction of limits. In case studies, obtained data is quite powerful in terms of reality. Moreover, the findings are available for interpretation and direct use (Cohen \& Manion, 1994, p. 123). Additionally, when researchers are an observer in the research, they are also able to be a participant for evaluating the subject as a part of the process (Y1ldırım \& Şimşek, 2005, pp. 77-78). In this study, one of the researchers also participated as an observer/actor. Participant interviews can also be useful for interpreting mathematical thought and abstraction during the interview (Geray, 2006, p. 171). As such, it is appropriate for the study and makes it more specifically a descriptive case study, which generally requires obtaining detailed information about a phenomenon to ensure data for future comparative studies (Merriam, 1988).

\section{Sampling/Study Population}

The participants of this study were two $12^{\text {th }}$-grade students enrolled in an high school in a large city of Turkey's central Anatolia region. Both students are female and their math teachers reported them as successful with excellent grades in their math courses. They are also very direct, curious math students. Additionally, these students voluntarily participated in the study and had not previously studied limits. They had already learned the subjects of series and functions, which is needed to acquire limit knowledge. The students were given the monikers of Zehra $(\mathrm{Z})$ and Gizem $(\mathrm{G})$.

\section{Data Collection Tools}

Abstraction happens in the problem-solving process, but according to Hershkowitz et al.'s (2001) research, all problems do not lead to abstraction. For this reason, three problems were arranged by the researchers in order to reach construction within the abstraction process, to reveal students' mathematical thought levels and knowledge abstraction process, and to develop a new structure. These problems are additionally from the areas students are quite likely to encounter in daily life, such as:

1. Ali heads to a tree 20 meters away by first covering half the distance, then half the remaining distance, and again each time, half of the remaining distance. Will Ali be able to reach the tree like this?

2. Two students play a game approximating a number by following the rules given below. A number is chosen. One student says two real numbers, one always bigger and the other always smaller than the chosen number. The purpose of the game is to say a number closest to the chosen number. The student who is unable to say numbers closer than the opponent's loses the game. For example, let's suppose students play the game choosing the number " 6 ." 


\section{$1^{\text {st }}$ student $5.5 \quad 5.9 \quad 5.97 \quad 5.992 \quad 5.9997 \quad \ldots \ldots$ \\ $2^{\text {nd }}$ student $6.5 \quad 6.09 \quad 6.02 \quad 6.001 \quad 6.0003 \quad \ldots \ldots$}

Who do you think will win the game?

3. A baby kangaroo is learning to jump. Every day it tries hard to jump higher. Let the number of jumps which the kangaroo makes be $x$. The height that this kangaroo can jump is expressed with the function of $f(x)=(4 x-1) / 2 x$.

a) Calculate the empty boxes below.

$\begin{array}{llllllllll}x \text { number of jumps } & 1 & 2 & 5 & 10 & 100 & 1000 & 10000 & 100000 & 1000000+\infty\end{array}$

$\underline{\mathrm{f}(x) \text { in meters }}$

b) What is the maximum height the kangaroo can jump?

c) If $f: A \rightarrow B$, find sets $\mathrm{A}$ and $\mathrm{B}$.

d) Is this function a sequence at the same time? Why?

e) If this function is a sequence, what value does it approximate?

f) What is the desired $x$ of function $f(x)$ when going to $+\infty$ ?

g) Is there a relationship between the desired value of a function and the value that a sequence approaches?

All these problems relate to the first and second acquisitions of the high-school mathematics curriculum. Therefore, all these problems completely relate to abstracting limit knowledge. The aim of the first problem is to let students anticipate the need for limit knowledge through their thought process and to construct the limit from only one side. The second problem aims to give students the opportunity to intuitively construct limit knowledge approaching a point and to consolidate limit knowledge from one side. Additionally, the third one is organized with functions for intuitively constructing limit knowledge as a whole. Accordingly, these problems allow for constructing limit knowledge by approaching any real number from the right or left, and constructing a value upon a series that converges at the same time it is equal to the series limit. A research expert participated in the study in order to determine the ease of problems for applying the $\mathrm{RBC}+\mathrm{C}$ model. Five experts were also asked for their opinions about the ease of these problems for learning limits, and the problems were rearranged in the direction of their suggestions. For example, "remaining" was put in the first problem by two of the experts so the problem could be solved correctly. 


\section{Procedure}

Semi-constructed interviews and observations were the data collection methods used in this research. Prior to the study, the aim and scope of the study were explained to the school administration and participating students in detail. Then in the fall semester of the 2014-2015 academic year, these students studied the research problems at the same time together. Within the scope of this study and in order to reach a conclusion, the students were asked to approach any real number from the right or left according to the information given for different events, form a list, and fill in the gaps in the given table by using the data in this list. In the meantime, one of the researchers participated in the study as a participant observer. The process was recorded with a video camera that students could see. This was to prevent forgetting the environment in which the observations and interviews were being conducted. At the same time, the recordings allow the researcher to review them as often as wanted so as to delay a final decision until being sure about the most appropriate approach and which points to highlight. Hence, the researcher was able to find rare or frequent events by fast-forwarding/rewinding the recording and, before making a decision about an event, change or correct her interpretations by looking at the previous/ subsequent events (Plowman, 1999, as cited in Topbaş, 2008).

\section{Analysis of Research Data}

The data was analyzed and interpreted using a descriptive analysis of the worksheets, including the answers students gave to the research problems and the videos recorded during the interviews. The aim of analysis is to present the obtained data in an organized and interpreted way. With this aim, the obtained data is described systematically and clearly (Yıldırım \& Şimşek, 2005, p. 224). At this stage, the dialogues recorded during the interview were listened to several times and transcribed into statements/texts in the study. This data is to be examined, and the obtained information should be divided into meaningful sections (Kümbetoğlu, 2005, p. 155). Accordingly, the $\mathrm{RBC}+\mathrm{C}$ model was applied to the statements in the application/ abstraction process, and these statements were analyzed over the cognitive actions of this abstraction model. In this context, the themes determined and used for analyzing the written interview statements are recognizing, building-with, constructing, and consolidating. In other words, these cognitive actions were observed and recorded collectively in the solution of each problem by two of the researchers, independent of each other. The definitions of these cognitive actions and examples related to these actions for the problems in this research are given in Table 1. 
Table 1

Cognitive Actions of the RBC+C Abstraction Model

\begin{tabular}{|c|c|c|}
\hline Action & Definition & Examples \\
\hline Recognizing & $\begin{array}{l}\text { Includes formal or informal information } \\
\text { that an individual has acquired before and } \\
\text { their attribution of meaning to mathemati- } \\
\text { cal elements in the learning environment. } \\
\text { It raises individual awareness of what kind } \\
\text { of foreknowledge is needed in order to } \\
\text { learn new information. }\end{array}$ & $\begin{array}{l}\text { * Recognizing to use sequence in the first problem. } \\
\text { * Recognizing to use function in the first problem. } \\
\text { * Recognizing infinity in the second research } \\
\text { problem. } \\
\text { * Recognizing limit knowledge from one side in } \\
\text { the third problem. }\end{array}$ \\
\hline Building-with & $\begin{array}{l}\text { Relates to individual use of the pieces of } \\
\text { information that one already knows to con- } \\
\text { struct a solution applicable to the problem. } \\
\text { This cognitive action is nested in the other. }\end{array}$ & $\begin{array}{l}\text { * Using sequence and series knowledge to solve } \\
\text { the first problem. } \\
\text { * Using infinity knowledge to solve the second } \\
\text { problem. } \\
\text { * Using limit knowledge from one side in the } \\
\text { third problem } \\
\text { * Using functions to solve the first and third } \\
\text { problem. }\end{array}$ \\
\hline Construction & $\begin{array}{l}\text { Is partly changing known structures and, as } \\
\text { a result of this, constructing a new structure. }\end{array}$ & $\begin{array}{l}\text { * Constructing limit knowledge from one side by } \\
\text { recognizing and building-with the sequence, se- } \\
\text { ries, and functions in the first problem. } \\
\text { * Constructing limit knowledge at a point in the } \\
\text { third problem. }\end{array}$ \\
\hline Consolidat & $\begin{array}{l}\text { Requires enhancing the new structure } \\
\text { (Dreyfus et al., 2001a; Hershkowitz et al., } \\
\text { 2001). }\end{array}$ & $\begin{array}{l}\text { * Consolidating limit from the left or limit from } \\
\text { the right in the second problem. }\end{array}$ \\
\hline
\end{tabular}

In this context, students recognize their foreknowledge, build-with this knowledge for different purposes, and examine thinking styles used during the process of limitknowledge construction. Then the extent that students have constructed their limit knowledge and the pre-structures that were required is reported. Finally, interpretations were given according to the data in order to make sense of the described findings. The relationships between these findings and the conclusions drawn are presented in detail.

\section{Validity and Reliability of the Study}

The validity and reliability of this qualitative research study have been achieved by taking the strategies of conclusiveness, transferability, and reliability into consideration (Yıldırım \& Şimşek, 2005, pp. 264-272).

In this study, conclusiveness and consistency were achieved through expert examination. First an expert working in the field was asked to determine the ease of the problems, and five different experts were asked their opinions about how limit knowledge is learned through these problems. After that, these problems were rearranged per their suggestions. Additionally, the video recordings were examined and transferred to texts independently by each of the two researchers and placed into the determined themes. At this stage, the themes were classified into groups prepared by the researchers, and the researchers resolved any discrepancies through discussion and evaluation. While describing and interpreting the typical and changeable 
characteristics of the study in detail were used to achieve transferability, quoting from the obtained data as much as possible to obtain sufficient data for analysis was used to achieve reliability. Additionally, importance was given to classifying research data in accordance with the descriptive method, as well as to organizing and interpreting the determined themes. Moreover, attention was paid to writing the research findings with the characteristics of reasonability, appropriateness for individual experiences, conclusiveness, importance, and readability.

\section{Findings}

The interview was carried out over two successful $12^{\text {th }}$-grade students who participated in the study. These participants studied three different problems in this process, which lasted approximately 45 minutes.

The first problem (Ali heads to a tree 20 meters away by first covering half the distance, then half the remaining distance, and again each time, half of the remaining distance. Will Ali be able to reach the tree like this?) was prepared with the aim of having the students anticipate the need for limit knowledge using their thought process from only one side of the situation. At this stage, the students need to estimate each step of the procession. In this process, it is necessary to recognize and build-with, two cognitive actions related to the $\mathrm{RBC}+\mathrm{C}$ abstraction model, and knowing sequence and series are the pre-knowledge used in solving the problem. Therefore, these students are expected to think about the situation and inference limit knowledge accordingly.

The students read this problem together and started to discuss it. Below is an excerpt of their discussion.

Zehra5: Gone half at a time. (Looks at the paper and thinks)

Gizem6: Gradually decreasing...

Z7: (Nods her head.)

G8: Tries to approximate by gradually decreasing.

Z9: Yes... (Nods her head again and looks at the paper)

G10: These are the subjects that we saw last year, I mean; when we were in 11th grade ... (She points to the problem with her pencil and looks at her friend)

Z11: Series... (Looks at her friend)

G12: (Looks at her friend and nods her head) Actually, it can be done by reasoning the series ...

Z13: By using the total symbol ... (Plays with her ear and thinks)

G14: By using the total product symbol ... (Reads the problem by underlining the sentence of the problem with her pencil.) She asks, "Can Ali reach the tree?" I think Ali can. (Zehra approves her friend's opinion by nodding her head) 
Z15: All in all, 20 meters is a limited distance. Since the distance is in meters, it can be covered.

G16: (Nods her head in approval of what her friend has said) The distance is in meters, it can be covered.

Z17: Can be covered, I mean I guess it can be stepped.

G18: (Zehra points to her friend's worksheet) 1.25 , as we do in series, well this ...

Z19: Well ... hmm... (Tries to remember; taps the sheet with her pencil and hands)

G20: Hmm... If we write 20 in the formula of total function ...

Z21: We write 20.

G22: Hmm...

Z23: Will we start from below 1, too? (Points to the problem on her friend's sheet) Won't we start from 1? Starting from 1 until $20 \ldots$ (Looks at her friend as if waiting for approval)

G24: Is it 1 ? How?

Z25: Well, in the end, he always covers half the distance...

G26: He goes in series.

Z27: He went in series.

(They talk at the same time looking at each other and nodding their heads in approval).

G28: Half, half, half, half.

Z29: Half, half, half.

Researcher30: How do you think Ali can reach the tree mathematically? (In the meantime, the students look at the researcher carefully) Can you relate it to the subject of series that we saw in 11th grade?

G31: I think he can... (First she looks at the sheet, than explains) In the lesson, we dropped the ball from a high place. Then it reached the highest [bounce], this is the same. (She looks at the researcher and her friend and shows the ball's path of movement bouncing with decreasing height using her hand) Just a tree intervenes. It's the same here, too. A certain...??? one. At a certain step.

Z32: (Points at the problem) I mean, in the end, a net... between Ali and the tree...

G33: Distance...

Z34: He gradually approximates since it is a distance.

G35: Yes. (They nod their heads, looking at each other.) He will go at a certain function, decreasing, but in the end, (marked the place where the tree is) he reaches.

Z36: He will reach.

G37: The reasoning is the same in series... (Points to the problem text in the sheet with her finger) If we put it in series, we can solve it over the series.

R38: Well, what kind of sequence is it? Is it a geometrical sequence or an arithmetic sequence? 
G39: A geometrical sequence (Looks at her friend's face and waits for approval)

Z40: A geometrical sequence ... (Looks at the researcher)

R41: A geometrical sequence? Can you obtain a net result with the formula of a geometrical sequence?

G42: Yes... (The students nod their heads)

Z43: Remember, the highest and the smallest number ...

R44: Do you remember how you did it?

G45: Remember what? The formula?

R46: If such a problem were asked in the subject of sequences, do you remember how you would solve it? (They look at the sheet).

G47: We write the summation symbol, then we write 20 on topside and start from 0 and decrease by $(1 / 2)^{n}$. We put it in the bracket of $1 / 2,1 / 2$ plus square of $1 / 2$ plus $(1 / 2)^{n} \ldots$ (Pointed to the worksheet with pencil) In the end, we will equalize it to 20 and from that sequence... well, we'll be able to find that sequence. (In the meantime, Zehra looks at the researcher, her friend, and the worksheet.)

R48: You were saying that he would reach this tree in the end?

G49: Yes, he reaches there in the end.

R50: By doing procedures in this way. (The students nod their heads.)

The interview texts given here (Z11, G12, Z13, G14, G18, G20, G26, Z27, G35, Z36, G37, G39, Z43, G47 and G49) indicate that the students recognized knowing the sequence, series, and function are necessary to solve the problem and thought to build-with in the solution of problem. These interview texts indicate the fact that Gizem and Zehra constructed the limit from one side.

After that, the second problem was directed to the students as follows:

Two students play a game approaching a number by following the rules given below. A number is chosen. One student says two real numbers, one always greater and the other always less than the chosen number. The purpose of the game is to say numbers that are closer to the chosen number than the previous ones. The student who is unable to say a number closer than this rival's loses the game. For example, let's suppose the students play the game for the number "6."

$1^{\text {st }}$ student $\quad 5.5 \quad 5.9 \quad 5.97 \quad 5.992 \quad 5.9997 \quad \ldots \ldots$

$2^{\text {nd }}$ student $6.5 \quad 6.09 \quad 6.02 \quad 6.001 \quad 6.0003 \quad \ldots \ldots$

Which one do you think will win the game?

This second problem was prepared with the aim of having the students recognize and build-with infinity as pre-knowledge in solving the problem. Additionally, they 
consolidated knowing the limit from one side, and began to recognize and build-with it to construct knowledge of the limit at a point. In other words, students were expected to know how to construct the limit at a point in this problem. At this stage, they read the problem and then discussed it for a while. The conversation text is given below.

Z51: Now we have the number ' 6 ' at hand. One says a number greater than 6 , the other says a number less than 6 .

G52: (She nods her head in approval of what her friend is saying) And the other says a number less than 6 .

Z53: As a result, always ... (She draws her hands near and away)

G54: Move them away from each other and say things. Well... (Shows the numbers in the sheet) It seems that 5.9 is less than 6.001. One says numbers that get smaller, the other says numbers greater than 6. (Zehra nods her head in approval of her friend) But which one wins? (They look at the sheet and think it over.

Z55: As a result, one is decreasing while the other is increasing ...

G56: I think... no... (She shakes her head in disapproval)

Z57: In every way, the same ... (She draws her hands near)

G58: They say the same. They can always say numbers less than 6 . Those which are greater than 5 as well.

Z59: The numbers which are greater than 6 as well... She asks which student wins... Which one says a closer number? (Looks at her friend. Gizem also points to the numbers on the sheet; Zehra looks at her.)

G60: Now, I wonder, when this says 6.02, will the other say 5.9 again? (Zehra points at the sheet)

Z61: They said these. When one said 6.02, the other said 5.97.

G62: He will never say those numbers again ... (Zehra agrees with her friend) Then numbers greater than 6 can go on infinitely. I mean he has a chance to say all the numbers.

Z63: Yes, I mean, it goes on in every way.

G64: And this to the lesser ones... (She looks at her friend as if waiting for approval)

Z65: He will say the smallest numbers infinitely. I mean they will not come across.

G66: I think they will tie. (Zehra nods her head agreeing with her friend. Then they look at the researcher.)

Z67: No one will win.

R68: Why did you draw such a conclusion?

Z69: Because there are infinitely many numbers on both sides ... Both less than and greater than 6 .

R70: We can choose infinitely many numbers that are closer to 6 . (The students nod their heads in agreement with the researcher). 
The interview texts given here (G62, Z63, G64, Z65, and Z69) indicate that the students recognized the concept of infinity, which is necessary when solving for it, and built-with it in solving the problem. Accordingly, the texts (Z51, G52, Z55, and G58) given here show that Zehra and Gizem consolidated the limit of one side. Other texts (G60, Z61, G62, and Z63) show that they began to recognize and build-with this knowledge. Additionally, some (Z57, G58, G62, Z63, G64, G66, Z67, and Z69) led researchers to think the students began at one point to intuitively construct limit knowledge.

Finally, the following was given to the students as the third research problem.

A baby kangaroo is learning to jump. Every day it tries hard to jump higher. Let the number of jumps the kangaroo makes be $\mathrm{x}$. The height that this kangaroo can jump is expressed with the function of $f(x)=(4 x-1) / 2 x$.

This last problem was organized with functions to formally construct students' limit knowledge as a whole. They were expected to recognize and build-with knowledge such as function, infinity, real numbers, and sequence as pre-knowledge in solving this problem. The students need to recognize and build-with their knowledge of limit from the left and limit from right, and to construct knowledge of limit at a point in this problem. At this stage, they read the problem and then discussed it for a while. The conversation text is given below.

First of all, the students were asked to read Section A of the problem:

Calculate the empty boxes below.

$\begin{array}{llllllllll}\mathrm{X} \text { number of jumps } & 1 & 2 & 5 & 10 & 100 & 1000 & 10000 & 100000 & 1000000+\infty\end{array}$

$\underline{\mathrm{f}(\mathrm{x}) \text { in meters }}$

Then they were asked to interpret it together and fill in the spaces left blank in the table. A partial text belonging to the interview held at this time is given below.

Z71: When $x$ is 1 , it becomes $3 / 2$.

G72: When we put 2, we get 7/4. (She looks at her friend as if waiting for approval) When we put 5 , we get $19 / 10$. When we put 10 , we get $39 / 20 \ldots$ It goes like this. (Zehra approves and writes, too.)

G73: Let's try 1000. 3,999/2,000. When we put 10,000, we get 399,999/200,000. (They write their results).

The partial interview text given here (Z71, G72, and G73) indicates that the students recognized and built-with the knowledge of function, which is necessary for solving the problem. Then the students continued to work, answering Section B of the problem (What is the maximum height in meters that the kangaroo can jump?).

G76: It is in meters. Gradually decreasing from $3 / 2 \ldots$ I mean as the number of jumps increases. (Zehra nods her head) 
Z77: Yes, then the maximum value will be its first value ...

G78: Its maximum value is its first value... The highest value becomes $3 / 2$, or 1.5 meters...

Z79: (Nods her head) 1.5 meters. As the number of jumps increases...

G80: For as the number of jumps, its value decreases in meters. For this reason, 3/2... maximum...

R81: Can you explain in more detail?

G82: As the number of jumps increases, $f(x)$ gets smaller.

Z83: As if $f(x)$ goes infinitely by getting smaller $\ldots$

R84: Examine once more, if you like. (The students look at the sheet)

G85: No, bigger. 1.75 looks...

Z86: Oh! Right... (Gizem nods her head and points to the table with her pencil)

G87: As $x$ number of jumps increases, so does the value of the $f(x)$ function. I mean when $x$ jumps once (1), it becomes 1.5 meters, but when it jumps twice (2), it becomes 7/9, I mean like $1.75 \ldots$

Z88: Later on it goes to 1.9 , anyway.

G89: Yes, after that 1.95. I mean as $x$ number of jumps increases, the value of the function gets bigger, too. But, we cannot know its maximum value. (They look at each other) One minute, as if it gradually approximates to 2. (Zehra puts her hand on her chin)

R90: Which values did you find?

G91: First we found 1.5, then $1.75,1.9,1.95$, and 1.9995. Finally, it approximates to 2 . It approximates to a maximum of 2 .

Z92: (Zehra looks at Gizem and nods her head) Actually it approaches 2, the values are smaller than 2.

G93: Yes. We cannot find its highest value.

Some interview texts given here (G85, Z86, G87, Z88, G89, G91, Z92, and G93) indicate that the students recognized and built-with the knowledge of infinity, function and the limit from one side, which is necessary for solving the problem. After that, the students were asked to answer Section $\mathrm{C}$ of the problem (If $f: A \rightarrow B$, find sets $\mathrm{A}$ and $\mathrm{B}$ ).

Z99: Then, will we think like $A$ going from 1.5 to 2 ?

G100: The definition set. (Gizem marks the column where $x$ is with her pencil and shows it to her friend).

R101: Yes, as the definition set and the image set...

Z102: Ok, Ok... (Zehra nods her head)

G103: $x$ is the definition set, and the values which we found in meters type (she shows her friend the $\mathrm{f}(\mathrm{x})$ column that she found in the table) will compose the value set. When we write 1 , its value becomes 1.5 . Then, when we write 2 , it becomes 1.75 . The definition set is $x$ number of jumps, and the image set is its value in meters kind. (Zehra approved by nodding her head) 
R104: In your opinion, what is the definition set? When we think of sets? Integer? Rational number?

Z105: The definition set has to be an integer.

R106: How?

G107: Positive integers.

Z108: Since $x$ indicates the number of jumps, $x$ (number of jumps) cannot be negative ...

G109: It has to be a positive integer.

Z110: I mean I cannot say it is a real number.

R111: Well, in your opinion, which values in which interval does the value set take?

Z112: The interval of $1.5-2 \ldots$

G113: The values approaching 1.5 and 2. Not 2 but... (Zehra approves by nodding her head)

From some of the interview text given here (Z105, G107, G109, and Z110), the students are understood to have had difficulty recognizing and building-with the knowledge of real numbers necessary for determining the intervals in this part of the question while solving the problem, but they did manage it. The students then held the following conversation with the aim of answering Section D of the problem (Is this function a sequence at the same time? Why?).

Z115: Now, according to the sequences which we learned in 11th grade, it increased by going to infinity but proportionally ...

G116: We do not know its value completely. We know which number it approaches. We do not know the full value.

Z117: I mean, yes, when $x$ went to infinity, it increased in the same way.

G118: Remember, there were sequence problems. For that reason, there is the same thing in this question, too, it approaches a value, but ...

Z119: Yes.

R120: Well, can you define a sequence for me? Do you remember what a sequence was? What is needed for a function to be a sequence?

G121: First of all... (Looks at the sheet)

Z122: (Looking at her friend) When a number goes to infinity, it yields the value it will take.

G123: It needs to increase or decrease proportionally. (In the meantime, Zehra nods her head and agrees with her friend) When it increases by 1.5 , the others need to increase by 1.5 , too.

R124: Can it be the definition of an arithmetic sequence, what you said? Do you remember how you defined the sequence?

G125: ...which positive integers take... (She puts her hand on her chin) 
Z126: The values which positive integers take when going to infinity.

R127: Well, do you think our jump function is a sequence, too?

Z128: Yes, it is an integer going to infinity.

G129: I think it is a sequence.

Z130: It is a sequence.

The interview texts given above indicate that the students recognized and built-with their knowledge of sequence, which is also necessary to answer the question while solving the problem. Then the students had the following conversation in order to answer Section $\mathrm{E}$ of the problem (If this function is a sequence, what value does it approach?)

R131: Well, if this function is a sequence, what value do you think it approaches? Which value does this function go to?

G132: It goes to the value of 2. For example; $1.9999 \ldots$

R133: How did you arrive at this conclusion?

G134: When we replace the values in the definition set with the function, the values increase. We started with 1.5 and I think since it approached 1.99995, it can at most approach 2.

Then the students held the following conversation in order to answer Section F of the problem (What do you think is the desired $\mathrm{x}$ value of function $\mathrm{f}(\mathrm{x})$ when it goes to $+\infty$ ?)

G138: We wanted to reach 2 in this sequence. For this reason, it is 2. (She shows the $f(x)$ column with her finger.)

Z139: We approach 2 and the numbers are less than 2.

G140: From the left. We approach from the left on the number line. (She brings her hands together as if showing the number line)

Z141: It seems as if $t$ approaches 2 from the left. (She brings her hands together as if showing the number line)

G142: We approach it from left. (Zehra nods her head) I think the desired value of the sequence is 2 .

With these research problems, the students are expected to generalize the results and make relations between the function and sequence to intuitively construct the knowledge of the limit at a point. The interview texts given here (G138, Z139, G140, Z141, and G142) let one consider that the students constructed the knowledge of the limit by building-with the limit from one side. Finally, the conversation held by the students for answering the question of the problem (Is there a relationship between the desired point of a function and the value to which a sequence approaches? Please discuss) is given below.

Z145: Now this question has a sequence. A sequence composed of integers. It comes from the left side. And our desired value is 2 and we approach this number with numbers less than 2. Now that there will be an intersection point between two in the end, this accumulation point may be an additional desired point of the sequence. 
G146: One more thing, remember what we said... We are trying to approach it with lesser numbers. Here we are trying to approach 2. I mean there can be a relationship between the value we are trying to approach in the sequence and the desired value. (Zehra approves by nodding her head) Then the desired value is related to the small or big numbers in the sequence.

Z147: It is advancing by increasing or decreasing.

G148: For example, there were such kinds of questions in the sequence, too. A ball was dropped from a height and its bouncing height decreased ... (She showed with her hand) And from here, we are approaching from a small number to a greater number ... But the result which we want to reach is the same.

Z149: Yes, definitely.

G150: If it had started with 1,000 bounces, it would still have reached 2. But it started with 1 bounce.

Z151: As a result, it again reached 2 with lesser numbers. And again its desired value is...

G152: Its desired value is 2. I mean, there is a relationship between them.

R153: Well, What did you calculate as the limit when it goes to plus infinity in this example?

G154: 2 (Zehra nods her head).

R155: You said 2. If our $\mathrm{f}(\mathrm{x})$ function is a sequence, what did you calculate as the value it approaches?

G156: We calculated it as 2 .

R157: Considering this, what can you say? What kind of an interpretation appears?

Z158: I mean... as a result it is an arithmetic sequence ...

G159: Does every sequence have a desired value?

Z160: Every sequence has a desired value.

G161: Because both the sequence and the desired value are trying to approach.

Z162: Approach or deviate.

G163: In my opinion, a sequence... (Thinks for a few seconds) As if the limit is the upper stage of the sequence.

Z164: I think the desired value covers the sequence...

G165: Yes, I'm thinking the same thing.

R166: You found the desired value of the function as 2. And you found the value to which the sequence approaches as 2 , also. Then, when it goes to infinity?

Z167: The desired value of a sequence going to infinity...

G168: Is it the same? They are equal.

Z169: Yes.

R170: What do you think are equal? Interpret. (They look at each other and think for a few seconds) 
G171: Both...

Z172: As a result, it goes to infinity. It also goes to infinity when it takes the desired value.

G173: As a result, it is a full value, as she found, but the sequence and the desired value are the same. Then, when the function $\mathrm{f}(\mathrm{x})$ approaches 2 , this approaches 2 , as well. Then the sequence and the desired value are the same. (She shows the table)

Z174: Because the value it approaches is 2 . Actually, they are equal in infinity. When it goes to infinity...

G175: It again takes the same value.

Z176: The value to which a number, a sequence, approximates and the desired value is equal for infinity. (They nod their heads)

R177: Yes, and this desired value is called the limit value.

Some of the interview texts given here (Z145, G146, G148, Z149, and Z151) point out that the students recognized and built-with the limit from the left side to construct limit knowledge. Similarly, other texts (G146, Z147, G148, Z149, G152, G156, Z160, Z167, G168, Z172, G173, Z174, G175, and Z176) show they recognized and builtwith the concepts of sequence, function, and infinity to construct the limit at a point.

\section{Discussion}

The abstraction processes of the two $12^{\text {th }}$-grade students were examined through the $\mathrm{RBC}+\mathrm{C}$ abstraction model in this research. The students' processes were examined using three research problems over the cognitive actions of recognizing, buildingwith, construction, and consolidation. These problems, which were designed by the researchers to reveal the students' mathematical thought-levels and abstraction processes, enabled the students to use their pre-knowledge and achieve a new structure.

Recognizing, the first cognitive action of this model, is necessary to construct the new structure. Also, this action requires using the second action, which means recognizing and building-with need to be used together to solve the problems. This is because the first one contains recognizing the concept of pre-foreknowledge to make it easier for the participants to study the problem in the process of construction and the second one requires them to use their pre-knowledge for this construction (Dreyfus, 2007; Hershkowitz et al., 2001). For this study, the students used the concepts of sequence, series, infinity, real numbers, and function as pre-knowledge to construct limits. All of these concepts were learned in their mathematics courses prior to this study. For example, real numbers occur in the mathematics curriculum as a $9^{\text {th }}$-grade subject, and functions occur as $9^{\text {th }}$ - and $12^{\text {th }}$-grade subjects. In the $12^{\text {th }}$-grade, knowledge of functions is the subject learned before limits. Therefore, the students were understood to recognize and build-with the concepts of sequence, series, and function in the learning process of limit knowledge as pre-knowledge for solving the first limit problem, as 
seen in conversation texts such as Z11, G14, Z27, G35, Z43 and G47 for the abstraction processes analyzed through the cognitive actions of the $\mathrm{RBC}+\mathrm{C}$ abstraction model in this research. Similarly, they recognized and built-with the knowledge of infinity in the learning process of limit knowledge for the second problem. Additionally, they began to recognize and build-with knowledge of approaching the limit from one side in this problem. These female students recognized and built-with the knowledge of infinity, function, and limit from one side to construct their limit knowledge at a point in the third problem. They also had some difficulties recognizing and building-with knowledge of real numbers, but were able to manage this, as well. They recognized and built-with knowledge of approaching a limit from one side and of sequence, function, and infinity for constructing the limit at a point, as seen such in texts G146, Z172, G173, Z174, G175, and Z176. This situation indicates that the participating students could exert their pre-knowledge for limits and explain the relationships between them.

Constructing is the most important act in the abstraction process because it requires a new structure to emerge using pre-knowledge, or in other words, changing known structures, recognizing and building-with in the learning process (Dreyfus et al., 2001a; Hershkowitz et al., 2001). In this action, participants need to organize and combine all their pre-knowledge to find a solution. In this research, a constructive learning environment was organized for abstracting students' limit knowledge, and as a result of the research, they were understood to have constructed the limit from one side in the solution of the first problem, as seen in texts such as Z13, G39, Z43, G47, and G49. Similarly, they began to construct the limit knowledge at a point, as seen in texts such as Z57, G58, Z67, and Z69 when solving the second problem, and constructed it in the third problem.

The last action, consolidation, was added to this abstraction model and detailed by Dreyfus (2007). The model can be said to be clarified and finalized in Dreyfus' research, and after that, researchers (Altun \& Y1lmaz, 2008; Sezgin-Memnun \& Altun, 2012; Yeşildere \& Türnüklü, 2008a, 2008b; etc.) generally focused on applying this model using different mathematical subjects. In this research, some of the interview texts indicate that the students consolidated knowledge of the limit from one side in the solution of the second problem.

The $\mathrm{RBC}+\mathrm{C}$ abstraction model explains the route that leads to abstract knowledge, as opposed to just learning it. As a result of the analysis made in relation to this abstraction model's cognitive actions of recognizing, building-with, construction and consolidation, Zehra and Gizem, whose mathematical achievement levels were high, can be said to have constructed limit knowledge. This situation indicates developing students' mental structures confirms these cognitive actions. Also, these explanations identify that abstraction was completed by these female students. Other studies (Altun \& Y1lmaz, 2008; Sezgin-Memnun \& Altun, 2012; Yeşildere \& Türnüklü, 2008a; etc.) have focused 
on the abstraction of different mathematical subjects, especially in Turkey, but they generally report that students construct the concept being researched. In this process, they recognized and built-with the knowledge of sequence, series, infinity, real numbers and function. Moreover, the students in this study were also observed to not have misconceptions about limits, indicating that this kind of study demonstrates an effective learning process for limit knowledge. This result overlaps with the results obtained by Akkoyunlu et al. (2003) and Bukova-Güzel (2007) in that it is appropriate to make use of activities, scenarios, subject-specific teaching strategies, and worksheets for teaching limits. Additionally, these results are similar to those obtained by Kula and BukovaGüzel (2015b) because they explain that pre-service teachers' special teaching methods are classified as representations and activities. At the same time, this study started from various small cases, and no misconceptions occurred. This result again supports the results obtained by Akkoyunlu et al. (2003), in that misconceptions can also be prevented in lessons by focusing on examining the behavior of the image of a function when the independent variable of this function is infinitely small. The participants were female students in this study and were able to construct the limits in their learning process, which were organized with problem-solving activities through constructivist learning, similar to the research obtained by Roh (2007) with a female student.

\section{Limitations and Suggestions}

This research is limited by the two participating $12^{\text {th }}$-grade students and three research problems organized by the researchers for this study. Therefore, researchers could examine the abstraction process of students from different grades over different mathematical subjects using the $\mathrm{RBC}+\mathrm{C}$ abstraction model in future studies. Additionally, further research might also include course designs that allow for teaching different subjects in accordance with the $\mathrm{RBC}+\mathrm{C}$ abstraction model.

\section{References}

Akbulut, K., \& Işık, A. (2005). Limit kavramının anlaşılmasında etkileşimli öğretim stratejisinin etkinliğinin incelenmesi ve bu süreçte karşılaşılan kavram yanılgıları [Investigation of effectiveness of interactive teaching strategy on understanding of limit concept and encountered misconceptions in this process]. Kastamonu Education Journal, 13(2), 497-512.

Akkoyunlu, A., Güler, M., Uğurel, I., \& Alan, E. (2003). Ortaöğretimde limit kavramının oluşturulmasına yönelik bir çalışma [A research on the construction of limit concept in high schools]. Retrieved from www.matder.org.tr

Altun, M. (2014). Liselerde matematik ögretimi [Mathematics teaching in high schools]. Bursa, Turkey: Aktüel.

Altun, M., \& Yılmaz, A. (2008). Lise öğrencilerinin tam değer fonksiyonu bilgisini oluş̧urma süreci [High school students' process of knowledge construction of the greatest integer function]. Ankara University Journal of Educational Sciences, 41(2), 237-271. 
Arslan, S., \& Çelik, D. (2015). Zor sanılan iki kavram: Limit ve süreklilik [Two concepts assumed to be difficult: Limits and continuity]. In İ. Ö. Zembat, M. F. Özmantar, E. Bingölbali, H. Şandır, \& A. Delice (Eds.), Tanımlarl ve tarihsel gelişimleriyle matematiksel kavramlar [Mathematical concepts with definitions and historical development] (pp. 463-487). Ankara, Turkey: PegemA.

Baki, A. (2008). Kuramdan uygulamaya matematik eğitimi [Mathematics education from theory to practice]. Ankara, Turkey: Harf Yayıncılık.

Baki, A. (2014). Matematik tarihi ve felsefesi [Mathematics history and philosophy]. Ankara, Turkey: PegemA.

Balc1, M. (2014). .Genel matematik I [Calculus I]. Ankara, Turkey: Sürat Yayınc1lık.

Barak, B. (2007). Limit konusundaki kavram yanılgılarının belirlenmesi [Determination of the misconceptions about limit subject] (Master's thesis, Balikesir University, Balikesir, Turkey). Retrieved from https://tez.yok.gov.tr/UlusalTezMerkezi/

Baştürk, S., \& Dönmez, G. (2011). Mathematics student teachers' misconceptions on the concepts of limits and continuity. Necatibey Faculty of Education Electronic Journal of Science and Mathematics Education, 5, 225-249.

Biber, A. C., \& Argün, Z. (2015). The relations between concept knowledge related to the limits concepts in one and two variables. Bartin University Journal of Faculty of Education, 4, 501515. http://dx.doi.org/10.14686/buefad.26967

Bukova-Güzel, E. (2006). Öğrencilerin limit kavramını algılamasında ve diğer kavramlarla ilişkilendirmesinde karşılaştıkları güçlükleri ortadan kaldırabilecek yeni bir program geliştirme [Development of a new program which resolves the difficulties about the understanding of the limit concept and relating it with the other concepts] (Doctoral dissertation, Dokuz Eylul University, Izmir, Turkey). Retrieved from https://tez.yok.gov.tr/UlusalTezMerkezi/

Bukova-Güzel, E. (2007). The effect of a constructivist learning environment on the limit knowledge among mathematics student teachers. Educational Sciences: Theory \& Practice, 7, 1155-1198.

Cajori, F. (2014). Matematik tarihi [A history of mathematics] (D. İlalan Trans.). Ankara, Turkey: ODTU Yayınc1lı.

Can, M. (2011). Matematiksel soyutlama ve soyutlamanın indirgenmesi [Mathematical abstraction] (Master's thesis, Yildiz Technical University, Istanbul, Turkey). Retrieved from https://tez.yok. gov.tr/UlusalTezMerkezi/

Çıldır, S. (2012). Visualization of limit in computer environment and the views of prospective teachers on this issue. Hacettepe University Journal of Education, 42, 143-153.

Cohen, L., \& Manion, L. (1994) Research methods in education. London, UK: Routledge.

Çoker, D., Özer, O., \& Taş, K. (1989). Genel matematik [Calculus]. Ankara, Turkey: Verso.

Creswell, J. W. (2009). Research design: Qualitative, quantitative and mixed methods approaches (3rd ed.). Thousand Oaks, CA: Sage.

Denbel, D. G. (2014). Students' misconceptions of the limit knowledge in a first calculus courses. Journal of Education and Practice, 5, 24-40.

Dönmez, G., \& Baştürk, S. (2010). Pre-service mathematical teachers' knowledge of different teaching methods of the limit and continuity concept. Procedia-Social and Behavioral Sciences, 2(2), 462-465. http://dx.doi.org/10.1016/j.sbspro.2010.03.044

Dreyfus, T. (2007). Processes of abstraction in context the nested epistemic actions model. Retrieved from http://cresmet.asu.edu/news/i2/dreyfus.pdf 
Dreyfus, T., Hadas, N., Hershkowitz, R., \& Schwarz, B. (2006). Mechanisms for consolidating knowledge constructs. In J. Novotná, H. Moraová, M. Krátká, \& N. Stehliková (Eds.), Proceedings of the 30th Conference of the International Group for Psychology of Mathematics Education: Vol. 2 (pp. 465-472). Prague, Czech Republic: PME.

Dreyfus, T., Hershkowitz, R., \& Schwarz, B. (2001a). Abstraction in context II: The case of peer interaction. Cognitive Science Quarterly, 1, 307-368.

Dreyfus, T., Hershkowitz, R., \& Schwarz, B. (2001b). The construction of abstract knowledge in interaction. Proceedings of the 25th Annual Conference for the Psychology of Mathematics Education, 2, 377-384.

Durmuş, S. (2004). Matematikte öğrenme güçlüklerinin saptanması üzerine bir çalışma [A research on the determination of learning difficulties in mathematics]. Kastamonu Education Journal, 12, 125-128.

Geray, H. (2006). Toplumsal araştırmalarda nicel ve nitel yöntemlere giriş [Introduction to the quantitative and qualitative methods in social research]. Ankara, Turkey: Siyasal Kitabevi.

Gürbüz, R., Toprak, Z., Yapıcı, H., \& Doğan, S. (2011). Ortaöğretim matematik müfredatında zor olarak algilanan konular ve bunların nedenleri [Subjects perceived as difficult in secondary mathematics curriculum and their reasons]. Gaziantep University Journal of Social Sciences, 10(4), 1311-1323.

Hassan, I., \& Mitchelmore, M. (2006). The role of abstraction in learning about rates of change. In P. Grootenboer, R. Zevenbergen, \& M. Chinnappan (Eds.), Identities, cultures and learning spaces: Vol. 1 (Proceedings of the 29th Annual Conference of the Mathematics Education Research Group of Australasia, pp. 278-285). Adelaide, Australia: MERGA.

Hershkowitz, R. (2004). From diversity to inclusion and back: Lenses on learning (Plenary lecture). In M. J. Hoines, \& A. B. Fuglesad (Eds.), Proceedings of the 28th Conference of the International Group for the Psychology of Mathematics Education: Vol. 1 (pp. 55-68). Bergen, Norway: PME.

Hershkowitz, R., Schwarz, B., \& Dreyfus, T. (2001). Abstraction in contexts: Epistemic actions. Journal for Research in Mathematics Education, 32, 195-222. http://dx.doi.org/10.2307/749673

Juter, K. (2006). Students' attitudes to mathematics and performance in limits of functions. Mathematics Education Research Journal, 17, 91-110. http://dx.doi.org/10.1007/BF03217417

Kula, S., \& Bukova-Güzel, E. (2015a). Reflections of mathematics student teachers' knowledge related to the purposes of the curriculum on their limit teaching. Journal of Theoretical Educational Science, 8(1), 28-49. http://dx.doi.org/10.5578keg8758

Kula, S., \& Bukova-Güzel, E. (2015b). The topic-specific strategies on the limit knowledge in mathematics student teachers' lessons. Milli Ë̆itim Dergisi, 44(206), 160-186.

Kümbetoğlu, B. (2005). Sosyoloji ve antropolojide niteliksel yöntem ve araştırma [Qualitative method and research in sociology and anthropology]. Ankara, Turkey: Bağlam.

Merriam, S. B. (1988). Case study research in education a qualitative approach. San Francisco, CA: Jossey-Bass Publishers.

Ministry of Education. (2006). Ortaöğretim matematik dersi (9, 10, 11 ve 12. sinıflar) öğretim programı [Teaching mathematics course program in high school]. Ankara, Turkey: Author.

Ministry of Education. (2013). Ortaöğretim matematik dersi (9, 10, 11 ve 12. sinıflar) öğretim programı [Teaching mathematics course program in high school]. Ankara, Turkey: Author.

Mitchelmore, M. (2002). The role of abstraction and generalization in the development of mathematical knowledge. Proceeding of the 9th East Asia Regional Conference on Mathematics Education and the Southeast Asian Conference on Mathematics Education (pp. 27-31). Singapore. 
Özmantar, M. F. (2004). Scaffolding, abstraction, and emergent goals. In O. McNamara (Eds.), Proceedings of the British Society for Research into Learning Mathematics: Vol. 24 (pp. 2). Retrieved from http://www.bsrlm.org.uk/IPs/ip24-2/BSRLM-IP-24-2-14.pdf

Özmantar, M. F. (2005). An investigation of the formation of mathematical abstractions through scaffolding (Doctoral dissertation, University of Leeds, Leeds, United Kingdom). Retrieved from http://etheses.whiterose.ac.uk/11271/

Özmantar, M. F., \& Monaghan, J. (2007). A dialectical approach to the formation of mathematical abstractions. Mathematics Education Research Journal, 19(2), 89-112.

Przenioslo, M. (2004). Images of the limit of function formed in the course of mathematical studies at the university. Educational Studies in Mathematics, 55, 103-132. http://dx.doi.org// B:EDUC.0000017667.70982.05

Roh, H. K. (2007). An activity for development of the understanding of the knowledge of limit. In J. H. Woo, H.C. Lew, K. S. Park, \& D. Y. Seo (Eds.), Proceedings of the 31st Conference of the International Group for the Psychology of Mathematics Education: Vol. 4 (pp. 105-112). Retrieved from http://www.emis.de/proceedings/PME31/4/104.pdf

Schwarz, B., Dreyfus, T., Hadas, N., \& Hershkowitz, R. (2004). Teacher guidance of knowledge construction. In M. J. Hoines, \& A. B. Fuglesad (Eds.), Proceedings of the 28th Conference of the International Group for the Psychology of Mathematics Education: Vol. 4 (pp. 169-176). Bergen, Norway: PME. Retrieved from https:/www.emis.de/proceedings/PME28/RR/RR175 Schwarz.pdf

Sezgin-Memnun, D., \& Altun, M. (2012). A research on the abstraction of the linear equation according to $\mathrm{RBC}+\mathrm{C}$ model: A case study. Cumhuriyet International Journal of Education, 1, 17-37.

Sierpinska, A. (1994). Understandings in mathematics. London, UK: Falmer.

Szydlik, J. E. (2000). Mathematical beliefs and conceptual understanding of the limit of a function. Journal for Research in Mathematics Education, 31(3), 258-276. http://dx.doi. org $/ 10.2307 / 749807$

Tall, D. (1988). The nature of advanced mathematical thinking. The Working Group for Advanced Mathematical Thinking for The Conference of the Physiology of Mathematics Education, Veszprem, Hungary.

Tangül, K., Barak, B., \& Özdaş, A. (2015). Students' concept definitions and concept images about the limit knowledge. Anadolu Journal of Educational Sciences International, 5(1), 88-114. http://dx.doi.org/10.18039/ajesi.48087

Tatar, E., Okur, M., \& Tuna, A. (2008). Ortaöğretim matematiğinde öğrenme güçlüklerinin saptanmasına yönelik bir çalışma [A research on the determination of the learning difficulties in high school mathematics]. Kastamonu Education Journal, 16(2), 507-516.

Topbaş, V. (2008). An examination of the teaching-learning process and teaching materials used in the instruction of geometry sub-learning fields in a first grade classroom. Ankara University Journal of Educational Sciences Faculty, 41, 299-323.

Tsamir, P., \& Dreyfus, T. (2002). Comparing infinity sets-A Process of Abstraction: The case of Ben. Journal of Mathematical Behaviour, 21, 1-23.

Vural, A., \& Cenkseven, F. (2005). Eğitim araştırmalarında örnek olay (vaka) çalışmaları: Tanımı, türleri, aşamaları ve raporlaştırılması [Case studies in education studies: Definition, types, steps and reports]. Süleyman Demirel Üniversitesi Burdur Eğitim Fakültesi Dergisi, 6(10), 126-139. 
Yeşildere, S., \& Türnüklü, E. B. (2008a). İlköğretim sekizinci sınıf öğrencilerin bilgi oluşturma süreçlerinin matematiksel güçlerine göre incelenmesi [Examining of abstraction processes of eighth grade students according to mathematical force]. Uludağ University Journal of Education Faculty, 21(2), 485-510.

Yeşildere, S., \& Türnüklü, E. B. (2008b). İlköğretim 7. sınıföğrencilerinin matematiksel soyutlama süreçlerinin incelenmesi: Üçgen eşitsizliği örneği [Examining of the mathematical abstraction processes of seventh grades students: An example of triangle inequality]. Paper presented at the VIII. Ulusal Fen Bilimleri ve Matematik Eğitimi Kongresi, Abant Izzet Baysal University, Bolu.

Yıldırım, A., \& Şimşek, H. (2005). Sosyal bilimlerde nitel araştırma yöntemleri [Qualitative research methods in social sciences]. Ankara, Turkey: Seçkin Yayıncılık.

Yılmaz, R.(2011). Matematiksel soyutlama ve genelleme süreçlerinde görselleştirme ve rol [Visualization and role in mathematical abstraction and generalization process] (Doctoral dissertation, Gazi University, Ankara, Turkey). Retrieved from https:/tez.yok.gov.tr/UlusalTezMerkezi/ 
